Patryk Witczak

DOI $10.15290 / \mathrm{sw} .2017 .17 .08$

Uniwersytet Kazimierza Wielkiego

Wydział Humanistyczny

Instytut Neofilologii i Lingwistyki Stosowanej

tel.: 523411797

e-mail: witczakptrk@wp.pl

\title{
Poezja emigracyjna Iriny Odojewcewej
}

Słowa kluczowe: Irina Odojewcewa, literatura emigracji rosyjskiej, literatura kobieca

Irina Odojewcewa (1895-1990, właściwie Iraida Gustawowna Heinike), na stałe zagościła już w świadomości czytelników i badaczy jako autorka głośnej dylogii wspomnieniowej $\mathrm{Na}$ brzegach Newy (Ha берегаx Hевы) i Na brzegach Sekwany (На берегах Cень) ${ }^{1}$. Na emigracji (od 1922) pisarka próbowała zaistnieć jako prozaik, autorka opowiadań i powieści poświęconych życiu emigrantów rosyjskich na obczyźnie. Jej utwory były ambiwalentnie oceniane przez krytykę emigracyjną2. Taki stan rzeczy mógł wynikać z faktu, że w Rosji Odojewcewa debiutowała jako poetka (Dwór cudów Двор чудес, 1922), a w petersburskim środowisku literackim znana była jako uczennica Mikołaja Gumilowa. Nie bez przyczyny Gleb Struwe w swojej

\footnotetext{
1 Pod koniec swojego życia Odojewcewa, pod wpływem namów Jurija Terapiano, zdecydowała się przystąpić do prac nad trzecim tomem memuarów, pt. $\mathrm{Na}$ brzegach Lete ( $\mathrm{Ha}$ берегах Летьл). Śmierć pisarki uniemożliwiła jednak te plany.

2 Nie wszystkie recenzje powieści Odojewcewej były negatywne. Emigranci młodszego pokolenia, tacy jak Władimir Warszawski czy Wasilij Janowski wypowiadali się na temat prozy swojej koleżanki dość pochlebnie, jednak dalecy byli w swoich ocenach od zachwytów. Swojego lekceważenia wobec twórczości Odojewcewej nie krył natomiast Władimir Nabokow. Patrz: [Сирин 2011, 633].
} 
rozprawie o literaturze rosyjskiej zagranicy pisze o Odojewcewej w podrozdziale zatytułowanym Proza poetów (Odojewcewa znalazła się tam w towarzystwie m.in. Borysa Popławskiego i swojego męża Georgija Iwanowa) [Струве 1996, 208-213]. Emigracja sprawiła, że pisarze rosyjscy, szczególnie poeci, mieli wiele problemów aby przystosować się do nowej sytuacji. Okazało się, że poezja, tak bardzo ceniona w Rosji, na Zachodzie nie wzbudzała wielkich emocji. Po raz pierwszy poetka przekonała się o tym przebywając w Rydze. Pełna wiary w swoją wielką sławę Odojewcewa udała się do Milruda - redaktora miejscowej gazety „Dzisiaj” („Сегодня”) - chcąc opublikować u niego kilka wierszy. Ku zdziwieniu emigrantki, redaktor nie tylko nie kojarzył jej nazwiska, ale ponadto stwierdził, że wierszy ma aż nadto, i lepiej żeby napisała niewielkie opowiadanie [Одоевцева 2008, 95-96]. Odojewcewa wyciągnęła wnioski ze spotkania z Milrudem i zwróciła się ku prozie. We wstępie do drugiego tomu swej słynnej dylogii autorka smutno konstatowała:

Я согласна с Мариной Цветаевой, говорившей в 1923 году, что из страны, в которой стихи ее были нужны, как хлеб, она попала в страну, где ни ее, ни чьи-либо стихи никому не нужны. Даже русские люди в эмиграции перестали в них нуждаться. И это делало поэтов, пишущих на русском языке, несчастными [Одоевцева 2008, 6].

W innym miejscu memuarów, wspominając jubileusz Borysa Zajcewa w 1926 r., Odojewcewa dodała:

Стихов я почти не писала. Зачем? Раз никому они здесь не нужны. «Хоть собственной кровью на скале, на необитаемом острове», как говорил Рёскин. Романтическое преувеличение. Стихи надо писать для современников, а не для проблематических потомков. Можно ли быть уверенным, что потомки найдут, прочтут и оценят мои стихи? Гораздо проще перестать писать их. Я так их делала [Одоевцева 2008, 326].

Powyższe słowa mogą budzić sporo kontrowersji, wbrew bowiem przeciwnościom losu wielu emigrantów, w tym Cwietajewa, na którą wcześniej powoływała się Odojewcewa, nie porzuciło poezji. Wydaje się, że w przypadku Odojewcewej chęć zaistnienia i bycia w centrum zainteresowania przeważyła nad miłością do poezji. Pisarka zdawała sobie sprawę z tego, że tylko dzięki prozie może zdobyć uznanie czytelników. O słuszności obranej przez siebie drogi utwierdził Odojewcewą sukces jej debiutanckiego opowiadania, pt. Spadająca gwiazda (Падучая звезда, 1926). Wedle zapewnień samej autorki, opowiadanie to miało zdobyć uznanie Iwana Bunina [Одоевцева 2008, 327]. 
Początkowe rozczarowania nie sprawiły jednak, że Odojewcewa na zawsze porzuciła poezję. Po II wojnie światowej wydała ona aż sześć tomików poetyckich: Kontrapunkt (Контрапункт, 1951), Wiersze napisane w czasie choroby (Стихи, написаннье во время болезни, 1952), Dziesięć lat (Десять лет, 1961), Samotność (Одиночество, 1965), Złoty tańcuch (Золотая иепь, 1975), Portret $w$ rytmizowanej ramie (Портрет в рифмованной раме, 1976). Można się więc pokusić o stwierdzenie, że dopiero przykre doświadczenia życia na emigracji sprawiły, że pisarka dojrzała wewnętrznie na tyle, że ponownie mogła zacząć pisać wiersze ${ }^{3}$. Ponowne zwrócenie się Odojewcewej ku liryce spotkało się z pełną akceptacją Iwanowa, który niezwykle wysoko oceniał powojenne próby pisarskie żony. Po ukazaniu się Kontrapunktu poeta w liście do Sergieja Makowskiego pisał:

[...] eе [Odojewcewej - P.W.] творчество за последнее два-три года сделало резкий (по-моему - ошеломляющий) скачок вверх, и эта новая книга, на редкость цельная и оригинальная, как нельзя лучше подходит, чтобы открыть ею поэтический бал, Вами задуманный. Я лично сейчас убедился, что ее стихи сплош и рядом выигрывают в сравнении с моими, и считаю, что ничего равного им в эмиграции (да и наверняка в России) не найти [Иванов 1955, 306].

Problematycznym jest przyporządkowanie twórczości Odojewcewej do określonego nurtu poetyckiego. W związku z tym, że jeszcze w Petersburgu była ona uczennica Nikołaja Gumilowa i związała się z petersburskim Cechem poetów, siłą rzeczy próbuje się emigrantkę zaliczyć do tzw. „byłych akmeistów", choć, jak przekonuje Gleb Struve, są to próby dość naciągane [Струве 1996, 219]. Jako żona Iwanowa i przyjaciółka Georgija Adamowicza wymieniana jest także niekiedy Odojewcewa wśród przedstawicieli „nuty paryskiej", jednak należy zgodzić się ze słowami Olega Korostelowa, który stwierdza, że poetce stylistycznie daleko zarówno do Iwanowa, jak i Adamowicza, a także całej filozofii młodych emigrantów rosyjskich tworzących w Montparnasse. Wydaje sie jednak, że moskiewski literaturoznawca zbyt jednostronnie i kategorycznie ocenił poezję Odojewcewej, konkludując:

Говорить о какой-либо философии, присущей ей, не приходиться. Жизнелюбие, брызжущее из ее стихов, противоречило главной сути неписаных канонов «парижской ноты». Лишь изредка в ее стихах появлялись строки, близкие заповедям Адамовича, но почти всегда врожденный оптимизм и восторг перед жизнью побеждали [Коростелев 2013, 327].

3 Większość z wymienionych cyklów poetyckich ukazała się już po śmierci Georgija Iwanowa w 1958 r. To wydarzenie niezaprzeczalnie odcisnęło silne piętno na Odojewcewej i zaważyło nad charakterem jej późnej twórczości. 
Owszem, Odojewcewa nie uległa w pełni dekadenckim nastrojom charakterystycznym dla rosyjskich egzystencjalistów w Paryżu, ale jej poezji nie można jednoznacznie określić mianem szczególnie optymistycznej, na co niewątpliwy wpływ miało życie osobiste pisarki. Należy przypomnieć, że w okresie międzywojennym Odojewcewa wraz z mężem żyła na wysokiej stopie dzięki regularnemu wsparciu finansowemu od ojca Gustawa Heinike - prężnie działającego ryskiego kupca. Po jego śmierci na początku lat 30. Odojewcewa odziedziczyła spadek, który umożliwił jej kontynuowanie dostatniego życia. Sytuacja zmieniła się po II wojnie światowej kiedy w wyniku działań wojennych i okupacji Paryża małżonkowie utracili praktycznie cały majątek i zaczęli utrzymywać się jedynie z honorariów, co nie było łatwe, pomimo tego, że Iwanow, uważany za jednego z lepszych poetów rosyjskich na emigracji nie miał większego problemu z publikowaniem swoich wierszy. Dodatkowo na początku lat 50. emigrantka ciężko zachorowała (podejrzewano gruźlicę), a w 1958 r. pochowała męża. Huśtawka emocjonalna, która towarzyszyła Odojewcewej w życiu prywatnym sprawiła, że podstawową cechą jej poezji jest ambiwalencja. Optymizm i pesymizm nieustannie toczą ze sobą walkę o diminację nie tylko w zbiorach poetyckich Odojewcewej, ale także w strofach czy nawet wersach poszczególnych wierszy. W jednym z liryków cyklu Dziesięć lat Odojewcewa oznajmia: „Как мне грустно... Как весело мне!" (Дождь шумит по грифельной крыше) [Одоевцева 1961, 18]. Fraza ta doskonale oddaje heterogeniczny charakter całej liryki autorki $N a$ brzegach Newy. Odojewcewa także w innych miejscach wskazuje na niejednorodność swego światopoglądu i emocjonalną binarność kreowanej przez siebie przestrzeni artystycznej. I tak, na rozdarcie wewnętrzne poetki, na chęć cieszenia się życiem pomimo przeciwności losu, wskazuje już tytuł pierwszego emigracyjnego cyklu poetyckiego Odojewcewej (Контрапункт). W teorii muzyki kontrapunkt oznacza technikę kompozytorską w utworach wielogłosowych, bądź też linię melodyczną towarzyszącą podstawowej melodii [Kopaliński 2007, 309]. Tak jak zapowiada tytuł zbiorku, w kolejnych wierszach emigrantki napotykamy na prawdziwą polifonię często sprzecznych emocji. W otwierającym Kontrapunkt wierszu Jestem dziś od rana wesota (Я сегодня с утра весела) czytelnik początkowo zostaje wprowadzony w optymistyczny nastrój:

Я сегодня с утра весела,

Улыбаются мне зеркала,

Олеандры кивают в окно.

Этот мир восхитителен... Но

[Одоевцева 1951, 5] 
Wypowiedź „ja” lirycznego akcentuje chęć cieszenia się życiem, które przecież przynosi tak wiele radości, jednak kluczowe w tej strofie słowo „ale" oznacza, że autorka przytoczonego monologu zdaje sobie sprawę z iluzoryczności i kruchości swojego szczęścia, które w każdej chwili może zostać zmącone. Do znacznej części wierszy Odojewcwej, nawet do tych, które pozornie uchodzić mogą za optymistyczne, zakrada się mrok nie pozwalający na osiągnięcie pełnego szczęścia. Na ten fakt zwróciła uwagę również Irina Fedorczuk. Szczecińska badaczka przekonuje, że w poezji lat 50. Odojewcewa pozostała wierna charakterystycznej dla siebie lekkości, ale jednocześnie lekkość ta nabrała smutnego odcienia [Fedorczuk 2012, 32]. Próbując rozstrzygnąć spór dotyczący tego czy Odojewcewa w swojej poezji prezentowała bardziej optymistyczną, czy też pesymistyczną postawę wobec życia, warto odwołać się do zadedykowanego przyjacielowi Jurijowi Terapiano wiersza Banalniejsze od banalnego (Банальнее банального), w którym autorka dokonuje swego rodzaju życiowego zestawienia zysków i strat i podsumowania dotychczasowej egzystencji:

Вот дни мои и все мои дела.

Как мало доброго. Как много зла.

Не то я делала, не так жила,

И ясно, что я лучше быть могла.

[Одоевцева 1961, 59]

Czytając powyższe wersy, trudno stwierdzić, że z poezji Odojewcewej wyzierała wręcz miłość do życia, jak to określił cytowany wcześniej Korostelow. Wraz z dojrzewaniem emocjonalnym poetka coraz wyraźniej zaczyna dostrzegać ciemniejszą stronę życia.

Podobnie jak w swoich memuarach, tak i w liryce Odojewcewa nieustannie zastanawia się nad sensem pisania wierszy oraz nad rolą poezji i poetów w życiu czytelników. Programowym dla emigrantki okazuje się utwór otwierający zbiorek Wiersze napisane w czasie choroby. Odojewcewa wyjawia w nim powody, jakie kierowały nią przy pisaniu kolejnych utworów poetyckich:

Мне казалось всегда, что писатель

Очень нужен на этой земле,

И что я для Вас, мой читатель,

Как тепло, как еда на столе.

Но какое Вам в сущности дело

До того, что я стать хотела

Другом Вашим, опорой в борьбе,

Утешеньем в горькой судьбе. 
Вот пишу я черным по белому,

По щемяще до слез сожалел ому,

Без утайки и без прикрас,

Откровенно, как в смертный час -

Обо всем, что я не сумела,

Как горела душа и болела,

Как томилась и как всецело -

Вами, с Вами, о Вас, для Вас.

[Одоевцева 1952, 7]

Niewielki (liczący dziewięć wierszy) cykl Wiersze napisane w czasie choroby opublikowany został w 1952 r., a więc wtedy, kiedy jego autorka, jak sugeruje sam tytuł, zmagała się z ciężką chorobą i przygotowywała na najgorsze. Stąd też niemal konfesyjny charakter nie tylko przytoczonego wyżej utworu, ale także pozostałych wierszy składających się na ten zbiorek. Poezja tworzona w tym czasieumożliwiła Odojewcewej w pełni wyrazić emocje. To wiersz, zdaniem emigrantki, jest najbardziej intymną formą dialogu pisarza z czytelnikiem, tylko poezja pozwala autorowi ściągnąć maskę i ukazać odbiorcom swoją prawdziwą twarz bez żadnych zakłamań. Autorka w obliczu ogromnego kryzysu egzystencjalnego przeklinała Blaise'a Pascala za jego nawoływania do akceptacji choroby i dostrzegania w niej pożytecznych aspektów, jednak jednocześnie próbowała swój ciężki stan wykorzystać przy pisaniu wierszy. Choroba staje się dla Odojewcewej aktem twórczym, swego rodzaju katalizatorem:

\footnotetext{
В этот час таинственно-ранний, В час ненужных воспоминаний Заклинаю страданье - исчезни! И чтоб мне простились грехи, Превращая болезнь в стихи.
}

[Одоевцева 1952, 8]

Okazuje się więc, że dopiero momenty przełomowe i tragiczne w życiu artysty są najbardziej inspirujące. Jewgienij Witkowski stwierdził, że to właśnie na początku lat 50. w swojej poezji Odojewcewa osiągnęła dojrzałość artystyczną, którą trudno było dostrzec w jej wcześniejszych próbach prozatorskich [Витковский, online].

W wierszu Zawsze byłam taka (Я всегда была maкой), odwołując się do ludowej baśni o rybaku i złotej rybce, porusza Odojewcewa problem pragnienia wieczności [Одоевцева 1976, 7]. W jej osiągnięciu pomóc może poezja, sprawiając, że życie nabiera sensu, którego tak wielu ludzi nie może 
znaleźć i dając szansę na życie wieczne w pamięci potomnych. Autorka przekonuje samą siebie:

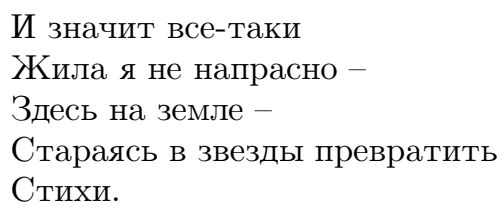

[Одоевцева 1976, 8]

Tworzenie nadaje życiu artysty sens i pomaga przetrwać najgorsze chwile w świecie tak bardzo wrogim poetom ( $В$ этом мире враждебном поэmaм). Możliwość znalezienia przy pomocy poezji sensu egzystowania i osiągnięcia nieśmiertelności okupiona jest jednak zdaniem Odojewcewej ogromnym poświęceniem. Pisarka, nawiązując do słynnego wiersza Charlesa Baudelaire'a, pt. Albatros, w którym francuski artysta porównuje poetów do albatrosów stworzonych nie do stąpania po ziemi, lecz szybowania w przestworzach, stwierdza, że bliżej jednak poetom do pelikanów:

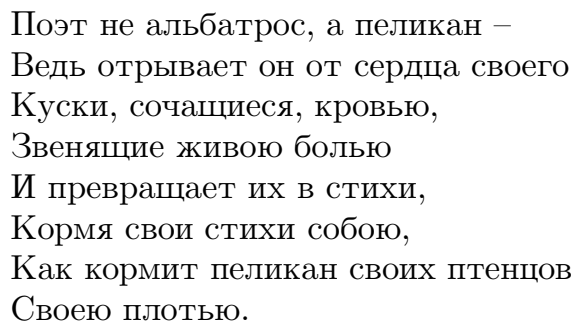

[Одоевцева 1976, 10]

Z tematem miejsca poety $\mathrm{w}$ świecie ściśle wiąże się problem emigracji i wyobcowania. Odojewcewa porównała Sekwanę do mitologicznej rzeki Lete płynącej w Hadesie i smutno konstatowała: „Мы последние поэты” (Piekło śródziemnomorskie - Средиземноморский ад) [Десять лет, s. 42], dając do zrozumienia, że rosyjscy poeci-emigranci pomału odchodzą w zapomnienie. Wypicie wód z rzeki Lete bowiem, wedle wierzeń starożytnych Greków, powodowało całkowitą utratę pamięci [Kopaliński 2007a, 168]. Utwór ten koresponduje zatem ze smutnymi konstatacjami Odojewcewej poczynionymi $\mathrm{w}$ memuarach na temat marginalnego znaczenia poezji w świecie Zachodu, symbolizowanego w tym przypadku przez Sekwanę. Na uwagę w omawianym wierszu zasługuje także określenie Francji piekłem śródziemnomorskim. Podobna rozumienie emigracji i statusu emigranta towarzyszy Odojewcewej nieustannie. Powraca również motyw piekła. Dla poetki życie na obczyźnie jest najgorszą karą, jaką można sobie wyobrazić - nawet Dante w swej 
Boskiej komedii nie opisał dotkliwszej („Такого наказания // Нет даже в дантовском Аду") [Одоевцева 1961, 50].

Paryż, Nicea, Wenecja i inne miasta Zachodu kuszą swymi pięknymi widokami, przepychem i rozrywkami, jednak to wszystko nie jest w stanie ukoić cierpienia emigrantów nieprzerwanie potęgowanego tęsknotą za utraconą ojczyzną. Na wygnaniu stopnie są kręte, a chleb ma gorzki posmak. Ludzie zamieniają się we własne cienie i pogrążają w otchłani. W obcym środowisku emigrantom towarzyszy poczucie niższości i ubóstwa, nie tyle materialnego, co przede wszystkim duchowego: „Я - нищий русский эмигрант" - оznajmia Odojewcewa [Одоевцева 1961, 50]. Oderwanie od ojczyzny sprawia, że człowiek stopniowo traci swoją tożsamość, zaczyna żyć nie swoim życiem:

Лазурный берег, берег Ниццы.

Чужая жизнь. Чужие лица.

Я сплю.

Мне это только снится.

До смерти так недалеко.

Рукой Подать.

[Одоевцева 1961, 49]

Pisząc o wewnętrznym zagubieniu i utracie własnego ja Odojewcewa sięga po motyw lustra, który często pojawia się nie tylko w jej poezji, ale także w prozie (wystarczy wspomnieć o powieści, pt. Zwierciadło - Зеркало) [Одоевцева 2011]. Zwierciadło wyróżnia się bogatą semantyką w kulturze. Przede wszystkim jest symbolem samopoznania. Jeśli nie rozpoznajemy swojego odbicia w lustrze, oznacza to, że utraciliśmy tożsamość [Kopaliński 2007c, 204]. W takim właśnie kontekście lustro pojawia się w wierszu Zaczęto się. I teraz zпоши (Началось. И теперь опять):

Все вокруг двоится, троится,

В зеркалах отражаются лица,

И не знаю я сколько их,

Этих собственных лиц моих.

[Одоевцева 1961, 16]

Zwierciadło można także rozpatrywać jako granicę między swoim i obcym, zewnętrznym i wewnętrznym, a także żywym i martwym. W poezji Odojewcewej obraz lustra możemy rozpatrywać zarówno w kontekście śmierci (samopoznanie), jak i granicy między różnymi światami. Szczególnie mocno motyw ten został zaakcentowany w wierszu Gtęboka noc. Daleko do świtu 
(Ночь глубокая. Далеко до зари). Ja liryczne odczuwa wyobcowanie i zagubienie w świecie, w którym się znalazło. Wszechobecne zwierciadła tylko nasilają poczucie obcości:

В дом незнакомый вхожу не звоня,

Сколько здесь комнат пустых, без огня,

Сколько цветов, сколько зеркал,

Словно аквариум светится зал.

[Одоевцева 1951, 9]

W ostatniej strofie wiersza zwierciadło staje się metaforą przejścia do świata zmarłych. Autorka monologu lirycznego tonie w tafli zwierciadła. Porównanie powierzchni lustra do tafli wody jest częstym zabiegiem literackim. Lustro wodne, w przeciwieństwie do szklanego zwierciadła wyróżnia się głębią. Na podobną symbolikę tafli wody (zwierciadła) zwrócił uwagę Jurij Lewin, który konstatował:

[...] водное зеркало [...] горизонтально, отражает небо (которое как бы опрокидывается в глубину) и ориентирует мир в соответствии с оппозицией верх/низ, контаминируя члены этой оппозиции 4 .

Emigranci zmuszeni do egzystowania w obcym sobie środowisku często odczuwali przerażającą samotność. Uczucie to jest wszechobecne także w liryce Odojewcewej, a szczególnie w wierszach napisanych już po śmierci Iwanowa. Samotność staje się nawet lejtmotywem cyklu pod takim właśnie tytułem (Одиночество). Interpretując zbiór Samotność Giovanna Spendel trafnie zauważa, że:

Стихи вошедшие в сборник Одиночество [...] пронизаны чувством отчужденности и одиночества, ощущением вечного скитальничества и невозможностью избавиться от навязанного ярлыка „изгнания” [Spendel 2007, 261].

Przygniatająca samotność często pociągała za sobą wśród emigrantów pytania o zasadność opuszczenia ojczyzny. Takie pytanie zadała sobie również Odojewcewa: „Зачем ты не осталась дома?” [Одоевцева 1965, 41]. Pytanie to pozostało bez odpowiedzi, a wyrazem tęsknoty za Rosją stały się nieustanne jej przywoływania w strofach kolejnych wierszy:

\footnotetext{
4 Lewin, s. 10 .
} 


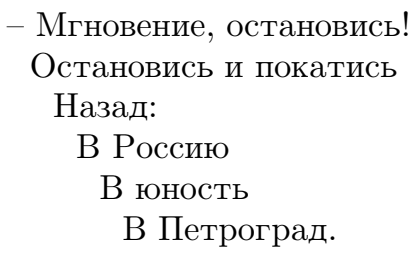

[Одоевцева 1965, 42]

Na zasadzie kontrastu w stosunku do Francji zrównanej z piekłem, Rosję Odojewcewa porównuje do Raju pełnego sielskich widoków, zapachu traw i smaku jabłek:

Сияет дорога райская,

Сияет прозрачный сад,

Гуляют святые угодники,

На пышные розы глядят.

[Одоевцева 1951, 16]

Nie tylko miłość do ojczyzny znalazła swoje odzwierciedlenie w poezji Odojewcewej. Wiele liryków, przede wszystkim tych składających się na cykl Kontrapunkt, poetka poświęciła także stosunkom między kobietą a mężczyzną. Inspiruje Odojewcewą jednak nie błogie spełnienie zakochanych, lecz momenty kryzysowe ich związku. Bohaterkom wierszy Odojewcewej towarzyszy nieustająca tęsknota za niespełnioną miłością. Niezależnie od tego czy przyczyną rozłąki jest zdrada ukochanego mężczyzny, czy też nieprzychylny człowiekowi los, zawód miłosny zawsze boli tak samo, a jedyną szansą na złagodzenie cierpienia nierzadko jest śmierć. W wierszu $W$ lekkiej łódce nа szuтnеј гzесе (В легкой лодке на шумной реке) Odojewcewa opisuje historię zrozpaczonej dziewczyny, która ukojenie znalazła w odmętach rzeki ( „Стало тихо и стало светло // Будто в рай распахнулось окно”). Pisząc o nieszczesśliwej miłości, zwraca się Odojewcewa ku zachodnioeuropejskiej klasyce i przywodzi słynne szekspirowskie bohaterki, które zginęły w imię miłości - Desdemonę i Ofelię (Гладью выцитый платок, За верность. За езумье тост, Об Офелии, о феe). Wśród kobiet, których okrutny los nie oszczędzał znalazły się również Eurydyka (Ночь в вагоне) i Leda (Тьг видишь как я весело живу).

Szczególnie poruszające są wiersze napisane przez Odojewcewą pod wpływem śmierci męża. Pisarka nie mogła wybaczyć sobie swej bezsilności w obliczu strasznego żywiołu śmierci. Najgorsze jednak jest życie po utracie najbliższej osoby. Poetce nieustannie towarzyszy rozdarcie wewnętrzne. Z jednej strony nie chce ona jeszcze umierać, z drugiej zaś - nie może znaleźć 
powodu, dla którego znalazłaby siłę, aby żyć i dalej walczyć z przeciwnościami losu:

\author{
Мне умирать, как будто, рано, \\ Хотя и жить не для чего. \\ Не для чего. Не для кого. \\ Вокруг - безбрежность океана \\ Отчаяния моего - \\ Отчаяния торжество.
}

[Одоевцева 1961, 52]

Po raz kolejny Odojewcewa pokazuje, że w życiu doświadczyła więcej przykrych chwil, niż tych, które sprawiły jej radość. Przypisywany jej przez niektórych badaczy optymizm był natomiast pozorny.

Irina Odojewcewa od początku swej drogi twórczej wzbudzała spore kontrowersje. Ponadprzeciętna uroda, bliska zażyłość z Gumiliowem, a następnie małżeństwo z Iwanowem sprawiły, że często powątpiewano w jej talent - ze zrozumiałych względów szczególnie krytyczna w stosunku do Odojewcewej była Achmatowa. Opublikowanie memuarów również nie przysporzyło jej przyjaciół. Wszystkie te aspekty sprawiły, że zupełnie zapomniany został poetycki dorobek pisarki, a przecież to on stanowił podstawę jej twórczości. To poezja tak naprawdę grała w duszy Odojewcewej. Utwory prozatorskie, w tym memuary, były pisane z innych pobudek - zostały niejako zdeterminowane losem emigranta. Tematycznie poezja Odojewcewej nie odbiega od twórczości innych emigrantów. Poetka pochyla się nad zagadnieniem roli poezji w życiu jej twórców i odbiorców, ciężkim losem emigrantów, wspomnieniami o utraconej ojczyźnie. Sięga pisarka do motywów miłosnych i funeralnych. Niniejszy artykuł stanowi próbę przywrócenia liryki Odojewcewej do dyskursu badawczego w Polsce i zainicjowania badań nad tą niedocenianą częścią jej spuścizny twórczej.

\title{
Literatura
}

Fedorczuk I., 2012, Эмигрантские лиры Георгия Иванова и Ирины Одоевчевой, [w:] Wschód-Zachód. Dialog języków i kultur, red. J. Kazimierczyk, P. Gancarz, Słupsk, s. 25-36.

Kopaliński W., 2007a, Stownik mitów i tradycji kultury, cz. II od K do P (Polikrates), Warszawa.

Kopaliński W., 2007b, Stownik wyrazów obcych i zwrotów obcojęzycznych z almanachem, cz. I od A do M (mi-parti), Warszawa. 
Kopaliński W., 2007c, Stownik symboli, Warszawa.

Spendel G, 2007, Мотивь изгнания в творчестве Иринь Одоевчнвой, [w:] Studia $i$ szkice slawistyczne X: Stowianie Wschodni na emigracji: literatura kultura - jezzyk, red. M. Giej, B. Kodzis, Opole, s. 252-262.

Витковский Е., «Мне нравятся неправильности речи...», [online] http://www. belousenko.com/books/Odoevtseva/odoevtseva_witkowsky.htm

Иванов Г., 1955, Писъмо Г. Иванова С. Маковскому от 19 декабря 1957 года, „Новый Журнал”, nr 201, s. 306.

Коростелев О., 2013, „Парижская нота” и противостояние молодежных поэтических школ русской литературной эмиграиии, [w:] idem, Oт Aдамовича до Цветаевой. Литература, критика, печать Русского зарубежья, Санкт-Петербург, s. 303-346.

Одоевцева И., 1951, Контрапункт, Париж.

Одоевцева И., 1952, Стихи, написаннье во время болезни, Париж.

Одоевцева И., 1961, Десять лет, Париж.

Одоевцева И., 1965, Одиночество, Париж.

Одоевцева И., 1975, Золотая иепь, Париж.

Одоевцева И., 1976, Портрет в рифмованной раме, Париж.

Одоевцева И., 2008, На берегах Сень, Санкт-Петербург.

Одоевцева И., 2011, Зеркало. Избранная проза, Москва.

Сирин, 2011, Ирина Одоевчева. Изольда. Изд. „Москва”, [w:] Одоевцева И., Зеркало. Избранная проза, Москва, s. 632-633.

Струве Г., 1996, Русская литература в изгнании, Париж-Москва.

\title{
THE EMIGRATION POETRY OF IRINA ODOYEVTSEVA
}

\author{
S U M M A R Y
}

Irina Odoyevtseva in 1918 moved to Petrograd and she joined the Second Guild of Poets, was tutored by Nikolai Gumilyov and become his favourite student. In 1923 Odoevtseva with her husband Georgy Ivanov emigrated to Paris. In this article author analyzes the evolution of the Irina Odoyevtseva creative imagination and the impact of the exile experience on the subject and imagery of her poetic work. 